University of Nebraska - Lincoln

DigitalCommons@University of Nebraska - Lincoln

2006

\title{
The Problem of Secular Sacredness: Ronald Dworkin, Michael Perry, and Human Rights Foundationalism
}

Ari Kohen

University of Nebraska-Lincoln,, akohen2@unl.edu

Follow this and additional works at: https://digitalcommons.unl.edu/poliscifacpub

Part of the Political Science Commons

Kohen, Ari, "The Problem of Secular Sacredness: Ronald Dworkin, Michael Perry, and Human Rights Foundationalism" (2006). Faculty Publications: Political Science. 37.

https://digitalcommons.unl.edu/poliscifacpub/37

This Article is brought to you for free and open access by the Political Science, Department of at DigitalCommons@University of Nebraska - Lincoln. It has been accepted for inclusion in Faculty Publications: Political Science by an authorized administrator of DigitalCommons@University of Nebraska - Lincoln. 


\title{
The Problem of Secular Sacredness: Ronald Dworkin, Michael Perry, and Human Rights Foundationalism
}

\author{
Ari Kohen
}

$\mathrm{T}$ he concept of human rights ultimately rests on the premise that there are some things that ought to be done for human beings and other things that ought not to be done to human beings in light of the fact that they are human. According to the Universal Declaration of Human Rights, these rights stem from the "recognition of the inherent dignity and of the equal and inalienable rights of all members of the human family" (Ishay 1997: 407). Some would argue that this notion has its roots in the natural law and natural rights tradition that is an important strand of Western political thought, ${ }^{1}$ and others would point out that Eastern philosophy neither ignores nor is fundamentally opposed to the concept of rights. ${ }^{2}$ Alternately, many people would claim that human rights have their origin in the Jewish and Christian traditions, whereas others would argue that nearly every major religion has its version of the Golden Rule. ${ }^{3}$ It may well be from the insistence that we treat others as we wish to be treated ourselves that we can deduce the rights we have today, but there is also a long-standing debate about whether rights can be found in traditional religious texts at all. In examining the Bible, for example, we might conclude instead that people have duties to one another - and to God but no rights, per se. ${ }^{4}$ To put a finer point on it, there are injunctions against killing and stealing in the Old Testament, but these do not necessarily correspond to rights to life and property; likewise, the New Testament encourages men to treat one another as they themselves want to be treated but does not provide a mechanism for anyone to claim injury in the event that they do not. In other words, these ancient religious texts do not seem to speak in the language of rights to which we have become accustomed. At the same time, strands of every major world religion seem to be quite supportive of the notion of inherent dignity, which underlies our contemporary understanding of human rights.

To say that religious texts are inclusive of human rights is very different from saying, as Michael Perry does, that a religious world view provides the only intelligible grounding for those rights. Indeed, the most provocative question is not whether the concept exists in each of the world's religions but whether it can exist independently of religion. As Perry (1998: 13) asks, 
What are we to make of such talk: talk about "the inherent dignity" of all hu-
man beings-about all human beings as members of one "family"-and about
the importance, therefore, of all human beings acting toward one another "in
a spirit of brotherhood"? It is easy enough to understand such talk as religious
talk ... But is it possible, finally, to understand such talk in a nonreligious ("sec-
ular") sense?

Others have attempted to answer these questions before, and in the first section of this article, the discussion focuses on a secular conception of human rights, as outlined by Ronald Dworkin. The second section considers Michael Perry's objections to Dworkin's theory of secular sacredness, whereas the final section presents my rebuttal to Perry's questions, quoted above, about the idea of human rights being a fundamentally religious one. Although both Dworkin and Perry suggest that human rights are based on sacredness, I argue that human dignity actually provides the foundation and that-contrary to existing theoretical work on this subject-sacredness and dignity should not be treated as synonyms.

\section{Toward a Secular Conception of "Sacred"}

In writing about the debates surrounding abortion and euthanasia, Ronald Dworkin (1994: 195) asserts that "there is a secular as well as a religious interpretation of the idea that human life is sacred." The religious version of human sacredness, Dworkin (1994: 79) notes, is easy enough to understand, because it is based on the notion that all livings things are "imaginative designs produced by God's inspired genius, to be honored as such." His secular vision, however, is considerably more complicated and is evaluated in greater detail below. Dworkin's (1994: 155) core claim is that "most people who are not religious also have general, instinctive convictions about whether, why, and how any human life has intrinsic value." Irrespective of the chain of reasoning behind it, Dworkin argues, most people acknowledge the intrinsic value of human life. ${ }^{5}$ At bottom, we believe that "it is intrinsically regrettable when human life, once begun, ends prematurely. We believe, in other words, that a premature death is bad in itself, even when it is not bad for any particular person" (Dworkin 1994: 68-69). Although he admits that there is a powerful critique of the idea of intrinsic value - simply put, that "objects or events can be valuable only when and because they serve someone's or something's interests" (Dworkin 1994: 69; italics mine) - he believes that he can provide a persuasive answer. "Something is intrinsically valuable," Dworkin (1994: 71) suggests, "if its value is independent of what people happen to enjoy or want or need or what is good for them." He notes that we often regard events and objects as being valuable in themselves and that, therefore, the idea is a familiar one to us; examples include "knowledge, experience, art, and nature" (Dworkin 1994: 71). However, he takes care to distinguish between these sorts of things, that are valuable incrementally, and things - like human life itself - that he suggests are "sacred or inviolable values" (Dworkin 1994: 70). In other words, although we believe that the more knowledge or experience we have the better, we believe differently 
about simply creating as much human life as possible: "It is not important that there be more people. But once a human life has begun, it is very important that it flourish and not be wasted" (Dworkin 1994: 74).

Some people may intuitively understand Dworkin's claim that certain things are valuable in themselves, regardless of whether this encourages us to increase our inventory of them or simply value those that are already in existence. ${ }^{6}$ Perry (1998: 26) concludes, however, that " $t$ ] he notion that something is valuable independently of a beneficial relation to anyone or anything - whether a human being, a nonhuman but living entity, or God-is perfectly opaque." It is, he notes, illogical to claim that something might be valuable in itself and, at the same time, have no value for anyone, as Dworkin seems to suggest. Instead, Perry (1998: 26) argues that something is intrinsically valuable when it "has value for someone (or something) not merely as a means to an end but as an end in itself." Strangely, the italicized portion of this quotation is less important to this discussion than the words that precede it, for the main difference between his and Dworkin's definitions of intrinsic value is that Perry maintains that things can only be intrinsically valuable if they have value for someone or something. Dworkin, he suggests, might have wanted to say that human life is objectively valuable, which would be "to say that something has value for someone (for example, that it is good for her, that it is conducive to or perhaps even constitutive of her flourishing) even if she is unaware that it has value for her-indeed, even if she believes that it has disvalue for her" (Perry 1998: 26). On my reading, Dworkin has indeed substituted intrinsic for objective value, setting the former in opposition to subjective value and omitting the latter entirely, but he has done so without equating value with benefit in the way that Perry insists he must. To do so, Dworkin (1994: 71) seems to suggest, would require yet another type of value: "Something is instrumentally important if its value depends on its usefulness." He notes, "David Hume and many other philosophers insisted that objects or events can be valuable only when and because they serve someone's or something's interests. On this view, nothing is valuable unless someone wants it or unless it helps someone get what he does want" (Dworkin 1994: 69). But, as Perry (1994: 178) argues,

The second sentence here is a glaring non sequitur. It does not follow, from the Humean view, that nothing is valuable unless someone wants it or unless it helps someone get what he does want. It follows only that nothing is valuable unless it serves someone's or something's interests. That something serves my interests does not entail that I want it (or that it helps me get what I do want). After all, I may not know that something serves my interests, or I may not know what my real interests are. Indeed, that I want something (or that it helps me get what I do want) does not entail that it serves my interests: I may want things that are not good for me-indeed, that are bad for me.

This trouble over the definition of intrinsic value is only the beginning of the disagreement between the two theorists. And the burden seems to fall on Dworkin (1994: 69), who says he will provide an answer to questions like, "How can it be important that a life continue unless that life is important for or to someone?" 
To answer this question, we must turn to Dworkin's suggestion that the current controversies over abortion and euthanasia can be traced to the fact that most people hold human life sacred. Although we generally associate "sacred" with the religious idea of holiness, Dworkin (1993: 36) argues that the sacredness of human beings can be held as a "secular but deep philosophical belief" rather than one that is necessarily religious in origin. Something might be held sacred when we attach a certain value to it, when we hold it in very high esteem. Perry's (1998: 26) initial rebuttal of this notion of secular sacredness is that intrinsic value, using his definition of the term, is necessary but not sufficient to establish sacredness: "An end to my itch has both objective and intrinsic value for me, but it is not thereby sacred." The reply that remains to Dworkin is that Perry's definition of intrinsic value is simply not as strenuous as his own. Under his own definition, intrinsic value is both a necessary and sufficient condition for sacredness, whereas Perry deliberately weakens his definition to leave room for the very problem he then demonstrates. The further challenge that Perry (1998: 26) presents to Dworkin, however, is a more difficult and engaging one: "For some persons who count themselves religious, to say that every human being is sacred is to say (speaking analogically) that every human being is the beloved child of God (God who is love). For persons who do not count themselves religious, what does it mean to say that every human being is sacred?" Unlike its predecessor, this challenge goes a great distance in pressing Dworkin's conclusions and provides a platform for this article's inquiry into the relation of human rights and human sacredness.

For Dworkin (1994: 74), "something is sacred or inviolable when its deliberate destruction would dishonor what ought to be honored." although this definition is not particularly helpful, the expansion that he undertakes is instructive. There are, Dworkin asserts, two ways in which something might be considered sacred. The first, sacredness by association, is explained through the example of flags and other national symbols: "Many Americans consider the flag sacred because of its conventional association with the life of the nation; the respect they believe they owe their country is transferred to the flag" (Dworkin 1994: 74). The second, sacredness based on creation, can be demonstrated by looking at our attitude toward endangered species or cultures. ${ }^{7}$ It is this second understanding of sacredness that Dworkin suggests is behind the feeling most people have about not wasting human life. This language of creation, he acknowledges, immediately brings to mind the notion that human beings are sacred because each is a child of God. He argues, however, that the same conservationist result can be obtained by secular means (Dworkin 1994: 76):

For most Americans, and for many people in other countries, the evolutionary process is quite literally creative, for they believe that God is the author of nature. On that assumption, causing a species to disappear, wholly to be lost, is destroying a creative design of the most exalted artist of all. But even people who do not take that view, but who accept instead the Darwinian thesis that the evolution of species is a matter of accidental mutation rather than divine design, nevertheless often use artistic metaphors of creation. They describe dis- 
crete animal species as not just accidents but as achievements of adaptation, as something that nature has not just produced but wrought.

There is an unmistakable connection drawn here between art and life. Indeed, the crux of Dworkin's (1994: 82) argument is that "each developed human being is the product not just of natural [divine or evolutionary] creation, but also of the kind of deliberative human creative force that we honor in honoring art." The first part of this claim is straightforward enough; human beings, he suggests, are considered sacred because they are the highest biological form of life. The second, however, requires some unpacking. What does it mean to say that each individual life results from deliberately applied human creativity? Here, Dworkin moves beyond the idea of sacredness as given to human beings by virtue of their biology (whether influenced directly by God or through natural processes) and focuses on sacredness as produced by human beings.

It is this move, from created to creating, that provides Dworkin with the most interesting component of his secular claim. He argues that both the decision to have a child and the child's life itself are creative endeavors. He notes that "a deliberate decision of parents to have and bear a child is of course a creative one. Any surviving child is shaped in character and capacity by the decisions of parents and by the cultural background of community" (Dworkin 1994: 83). It is not immediately clear, though, why Dworkin believes that the sacredness of persons flows from the decision of parents to have a child or from their shaping of its character. To provide a more thorough explanation of his word choice, Dworkin (1994: 83) returns to the idea of life as artwork: "As that child matures, in all but pathological cases, his own creative choices progressively determine his thoughts, personality, ambitions, emotions, connections, and achievements. He creates his life just as much as an artist creates a painting or a poem." This idea-that human beings shape their lives and, in a sense, create themselves - is the grounding of Dworkin's secular usage of sacredness. Of course, because his multipart definition contains both religious and secular elements, Dworkin is confident that it is sufficiently inclusive to command the respect of the religious and nonreligious alike. He is certainly correct in his assumption that those who believe that each human being is a child of God will agree with his claims about the sacredness of persons. Dworkin's nonreligious claim may not perform its function as effectively, however. Indeed, the process as outlined is certainly a creative one, but we might be justified in wondering whether it makes human life sacred or simply beautiful, unique, or important.

\section{Michael Perry's Objection}

The crux of Perry's complaint about Dworkin's secular sacredness proceeds from the assertion that a human life is a work of art made valuable as a result of natural and human investments. Summarizing the problem, he says, "Let us agree that every human being is a creative masterpiece and, as such, inspires (or should inspire) awe in us. That something justifiably inspires awe in us, how- 
ever-James Joyce's Ulysses, for example-entails neither that we believe it to be sacred nor that it is sacred" (Perry 1998: 27). For Perry, a sacred thing is one which-due to its sacredness-inspires awe in us and that, consequently, we value highly. ${ }^{8}$ Dworkin, however, reverses the order, suggesting that something is held sacred in response to its inherent value, to the awe it inspires in us. The problem with this reversal, according to Perry, is that it makes secular sacredness entirely subjective. Dworkin, he suggests, appeals to no objective standard in his argument for secular sacredness and thus leaves himself open to the possibility that others simply will not believe as he does about the value of humankind. He argues that "Dworkin seems to be using 'sacred' in what we can call a weak, or 'subjective,' sense-something (e.g., a human life) is sacred because, or in the sense that, it inspires awe in us and we attach great value to it-rather than in the strong, or 'objective,' sense-something is sacred and therefore it inspires awe in us and we attach great value to it" (Perry 1998: 28). To add specificity, Perry asks that we imagine using Dworkin's secular concept of human sacredness to change someone's mind about the human rights violation he is about to commit. He hopes that, in thinking through the discussion we might have with a Bosnian Serb intent on raping a Bosnian Muslim, we will come to the conclusion that an appeal to some objective standard carries more weight (Perry 1998: 28):

If "sacred" is meant in the subjective sense, the Bosnian Serb can reply: "Sacred
to you and yours, perhaps, but not to me and mine. In the scheme of things, we
happen not to attach much value to her life." By contrast, "sacred" in the objec-
tive sense is not fundamentally a matter of "sacred to you" or "sacred to me"; it
is, rather, a matter of how things really are ... . If every human being is sacred
in the objective sense, then, in violating the Bosnian Muslim, the Bosnian Serb
does not merely violate what some of us attach great value to; he violates the
very order of creation.

Although Perry's point is a compelling one, and one that Dworkin does not address, I am not entirely convinced that he has presented the knock-down argument to Dworkin's secular claim. Instead, Perry has raised three interesting and interrelated problems for himself with this example.

First, we might ask whether Perry is actually responding to Dworkin on his own terms. Because Perry questioned the definition of intrinsic value that Dworkin put forward and then simply proceeded with his own instead, he now misses an important component of Dworkin's argument. In failing to show conclusively that intrinsically valuable things must have value for someone or something, Perry leaves Dworkin free to argue that human life is valuable in itself and, in that respect, to provide an answer to the imagined Bosnian Serb. Nowhere, after all, does Dworkin suggest that skeptical people ought to be convinced that human life is sacred simply because it is valuable to him (or to us). Instead, Dworkin claims that human life is intrinsically valuable-valuable in itself-and, in doing so, he manages to side-step Perry's charge of subjectivity. Indeed, Dworkin's entire argument that human lives be considered creative masterpieces is his attempt to show that it is, in fact, possible for something to be valuable without 
its having value for anyone in particular. We are entitled, of course, to question whether Dworkin actually succeeds in demonstrating the intrinsic value of human life. And, indeed, a compelling case can be made against Dworkin on this question of intrinsic value. He has not, in fact, shown anywhere that events or objects should be considered valuable in and of themselves. ${ }^{9}$ He has, however, asserted that we believe some events or objects are valuable in this way. But is this sufficient to convince those who do not?

This question spills directly into the second problem, namely that in adding the concrete example of ethnic cleansing in Bosnia, Perry has altered his project in an important way. Rather than seeking to demonstrate that the only intelligible version of human rights is one that has its roots in religion, Perry now entertains the hope of convincing others of the virtues of the contemporary international human rights regime. That these are two very different projects is demonstrated nicely by Christopher Eberle in his discussion of moral obligation stemming from the Divine Command Theory (DCT). He notes that "Even if the Divine Command theorist can't justify the DCT to anyone else, it's possible that she's justified in adhering to the DCT: given the particularities of her epistemic condition, and in particular, given the other theistic claims she affirms, it's possible that her perspective on the world entitles her to believe that the DCT is true" (Eberle 2003: 4). This is very much in line with an argument that Perry makes in a recent essay about the religious nature of the notion of human inviolability. He sketches out the belief system of a woman whose faith helps her to love even those who are the most unfamiliar or remote, as well as those who harm her: "Sarah loves even those from whom she is most estranged and towards whom she feels most antagonistic: those whose ideologies and projects and acts she judges to be not merely morally objectionable, but morally abominable" (Perry 2005: 112-113). In agreement with Eberle, Perry (2005: 141) notes that "Sarah's religious position is embedded in - and it has whatever plausibility or implausibility it has because of its embeddedness in - a broader family of religious claims, especially the claims that (a) every human being is a beloved child of God and a sister or brother to one's self and (b) human beings are created by God to love one another."

The heart of the matter, then, is that Sarah and the Divine Command theorist are free to believe whatever it is that they would like to believe-just as I may justify my own beliefs in any way I might like - but they ought not assume that anyone else will be convinced by the same reasoning that convinces them. In our attempts to justify our beliefs to others, we ultimately reach a point beyond which we can rationally argue no further. This is true whether our beliefs are based in religion, nature, or reason. Even Immanuel Kant (1993: 61-62), upon completing his Grounding for the Metaphysics of Morals, recognized this problem:

Now it is an essential principle of all use of our reason to push its knowledge to a consciousness of its necessity (for without necessity there would be no rational knowledge). But there is an equally essential restriction of the same reason that it cannot have insight into the necessity either of what is or what does happen or of what should happen, unless there is presupposed a condition under which it is or does happen or should happen. In this way, however, the sat- 
isfaction of reason is only further and further postponed by the continual inquiry after the condition. Reason, therefore, restlessly seeks the unconditionally necessary and sees itself compelled to assume this without having any means of making such necessity conceivable; reason is happy enough if only it can find a concept which is compatible with this assumption .... And so even though we do not indeed grasp the practical unconditioned necessity of the moral imperative, we do nevertheless grasp its inconceivability. This is all that can be fairly asked of a philosophy which strives in its principles to reach the very limit of human reason.

Sarah, the Divine Command theorist, and Kant, must all eventually say, with Wittgenstein (1968: 85), "If I have exhausted the justifications I have reached bedrock, and my spade is turned. Then I am inclined to say: 'This is simply what I do.'”

Perry (2003), however, is critical of those-like Dworkin - who would attempt to convince others of the rightness of human sacredness either without first successfully specifying their source of normativity or whose source of normativity "doesn't withstand scrutiny even on its own (secular) terms." On this point, that there is something incomplete about the nonreligious argument, Perry notes that the assertion that all human beings are sacred and, as a result, inviolable, is simply a statement of the theorist's own preference for a world in which these beliefs are honored. The problem, however, is that this preference for a world that respects human rights does not necessarily line up with nonreligious beliefs about the way the world works. In agreement with Perry on this point is Jeffrie Murphy (1988: 247-248), who notes that "Liberal theorists have a self-destructive tendency to be charmed by views that undermine their own central doctrines - for example, a failure to realize that the liberal virtues of value pluralism and value tolerance may undermine the absolutism about human rights upon which liberalism ultimately depends." According to Perry (2005: 141-142), the problem is not simply one of competing liberal virtues; instead, it goes as deep as these theorists' core beliefs:

It is a presupposition of the nonreligious position that the universe is just what Clarence Darrow and Steven Weinberg (among others) have proclaimed it to be: a cosmic process bereft of ultimate meaning ... . Far from being created "in the image of God," human beings are merely the unplanned, unintended yield of random mutation and natural selection. But, lo and behold, it just happens that the evolved nature of human beings is such that being a person who "loves one another just as I have loved you" is the most deeply satisfying way of life of which human beings are capable. This free floating nonreligious position seems so ad hoc, as if those who espouse the position were determined to cleave to a consoling belief about human nature long after the religious vision in which the belief has traditionally been embedded has ceased to have, for them, credibility.

Perry charges, in other words, that nonreligious thinkers have embraced a cosmology that looks upon human existence as the product of random chance but hope to maintain a foundation for the idea of human rights. The problem is that 
such a contingent picture of human nature does not provide a solid enough grounding for human rights; this view, he argues, cannot possibly prove effective in the face of counterclaims by human rights abusers. This is a valid critique, but the religious position - despite specifying a source of normativity - also offers no assistance when the task is persuading those with different beliefs. Sarah believes that "By becoming [people who love one another as God loves us], we fulfill - we perfect-our created nature and thereby achieve our truest, deepest, and most enduring happiness. That fact, coupled with our commitment to our own authentic well being, is, according to Sarah, the source of normativity" (Perry 2005: 140). The problem, of course, is that Sarah's source of normativity is the result of her own deep yet personal religious commitment, a commitment that she cannot really justify to others in a convincing manner. As Perry (2003) notes, "Sarah specifies the source of normativity - though, of course, if one is a nonbeliever, or a believer of the 'wrong' sort, the source Sarah specifies will not move one."

This yields the third-and, in my opinion, most interesting-problem that Perry's critique raises. Indeed, it offers us an entrée into the central argument that underlies The Idea of Human Rights. In his critique of Dworkin, Perry (1998: 28) insists that "The premise that every human being is sacred-in-the-subjective-sense cannot begin to bear the weight of the premise that every human being is sacredin- the-objective-sense." By stating his objection in this manner, he alludes to the problem discussed above: that Dworkin's argument for secular sacredness is not convincing in the same way as the religious argument (or not convincing at all). Put succinctly, Perry contends that at the center of every human rights claim is the notion of the sacredness of persons, which is, contra Dworkin, a fundamentally religious concept. His project is to examine the various secular understandings of "the conviction that every human being is sacred-sacred in the strong/objective sense, sacred because of how the world really is, and not because of what we attach value to in the world" (Perry 1998: 29). But, in framing the search in this way, Perry sets an impossible task for others to accomplish. The closest that Dworkin (1994: 73) comes to succeeding is in his discussion of intrinsic value, where he poses a question that is notable for its conditional wording: "If it is a horrible desecration to destroy a painting, for example, even though a painting is not a person, why should it not be a much greater desecration to destroy something whose intrinsic value may be vastly greater?" Were he to remove the conditional wording and answer this question, which he does not, he would still fail in his project of suggesting a secular understanding of human sacredness. The best answer Dworkin can give is one he gave earlier: destroying a person would be a much greater desecration than destroying a painting based on the fact that we believe human lives to be intrinsically valuable or sacred, which is itself based on our belief that human beings are the most creative species in existence. But this is not the same as arguing that human beings actually are valuable in and of themselves, nor will it convince those with radically opposing beliefs to change their minds. How, after all, can we talk about something having intrinsic value in the absence of some external and unchanging measuring tool? As Perry (1998: 28) asks, "How do we get from 'the universe is (or might be) nothing but a cosmic process bereft of ultimate meaning' to 'every human being is nonetheless sacred (in the strong or objective 
sense)'?" How, in other words, might a human life be both sacred and low-level nuclear waste? To show that something is secular and sacred in the sense that Perry wants, one must actually show that it is religiously secular, which wouldof course-defeat the purpose.

The idea that something might be secular and religious at once is a difficult one to grasp and requires some investigation. The most fruitful way to do so is to continue our detailed examination of Perry's argument to see how he creates this puzzle. Both Perry and Dworkin attempt to draw political conclusions from the notion of the sacredness of persons. Just as Dworkin hopes to find a grounding for the debate about abortion and euthanasia, Perry wants to highlight the foundation of universal human rights. Dworkin, according to Perry (1998: 28, italics mine), has failed to show "that either a secular cosmology or cosmological atheism can yield the requisite conviction about how things really are." Although we can certainly question whether this was ever Dworkin's intent, we must also consider the reasonableness of Perry's demand. Is it possible, in the end, for secularists - people like Clarence Darrow or Steven Weinberg - to give to us a definitive answer about the nature of the universe? It seems unlikely that either could provide the sort of answer that Perry desires. Their inability to do so, however, threatens to leave the contemporary human rights regime with a severely eroded foundation, for Perry (1998: 12) insists on the intimate connection between human sacredness and human rights. In his own words: "The conviction that every human being is sacred is, in my view, inescapably religious - and the idea of human rights is, therefore, ineliminably religious." But what exactly is the connection between the sacredness of persons and the idea of human rights?

The question of whether there is something inherent in human beings from which our rights spring is fundamental to any attempt at understanding human rights claims. As Perry (1998: 30-31) says, "The fundamental challenge to each and every human rights claim ... is a demand for reasons." Indeed, this article began with an effort to trace the notion of grounding our rights and noted that one can look at least as far back as the Stoics in doing so. The importance of this search is nicely elucidated by Perry (1998: 13), who contends that "there is something about each and every human being, simply as a human being, such that certain choices should be made and certain other choices rejected; in particular, certain things ought not to be done to any human being and certain other things ought to be done for every human being." Despite overwhelming agreement that something about us is surely responsible for our having rights, theorists have not often been in agreement about what exactly that something might be. Enlightenment thinkers conclude that it is our ability to use reason; theologians suggest that it is our status as children of God, made in His image. And, of course, international human rights documents contend that it is our dignity that sets us apart from all of the other species.

For Perry, the foundational component of the idea of human rights is the conviction that every human being is sacred; it clearly relies, he argues, on a spiritual belief of one kind or another to be intelligible. Regardless of whether he is correct on that score, Perry (1998: 31$)$ is surely correct that 
The fundamental challenge to human rights claims is a real-world challenge: Many to whom such claims are addressed have conspicuously not adopted anything like "the moral (impartial, universal) point of view." The moral point of view is not a justificatory basis for human rights claims - at least not a fundamental basis. The moral point of view is itself in dire need of justification, especially in a world-our world, the real world - that is often fiercely partial/local rather than impartial/universal. His religious understanding of the sacredness of persons is an attempt at providing just such a justification. It represents, in his view, the only intelligible way to answer "what David Tracy has called the 'limit-question' of morality: 'Why be moral at all?'” (Perry 1998: 30).

As we have seen, Dworkin's secular conception of sacredness fails to provide a satisfactory answer to this question. Robert Grant (1993: 11) concludes a bit more forcefully that, "In Life's Dominion, Professor Dworkin makes considerable play with, indeed frankly exploits, the idea of the sacred, but shows no understanding of it." Indeed, considerable difficulties arise over his unconventional definition of intrinsic value and over his idea that each of us holds in higher esteem one of the two investments that make something sacred. In addition, and perhaps most importantly, there is the problem of subjectivity to which Dworkin's secular sacredness falls prey. As Perry (1998: 28) points out, "The premise that every human being is sacred-in-the-subjective-sense cannot begin to bear the weight of the premise that every human being is sacred-in-the-objective-sense." That said, it is important to avoid tossing away Dworkin's contribution entirely. Though somewhat the worse for wear on the question of sacredness, there is a very valuable point that Life's Dominion raises, namely the idea of self-creation. As discussed earlier, Dworkin argues that human life is valuable because of the creative contributions of both nature and humanity. The key component of this argument is the latter notion, the idea that each human being is created by her culture and community, as well as her own thoughts. On this point, Dworkin's (1994: 84) ideas are very well-articulated:

The life of a single human organism commands respect and protection, then, no matter in what form or shape, because of the complex creative investment it represents and because of our wonder at the ... processes of nation and community and language through which a human being will come to absorb and continue hundreds of generations of culture and forms of life and value, and, finally, when mental life has begun and flourishes, at the process of internal personal creation and judgment by which a person will make and remake himself, a mysterious, inescapable process in which we each participate, and which is therefore the most powerful and inevitable source of empathy and communion we have with every other creature who faces the same frightening challenge.

Put succinctly, each human life is inherently valuable because human beings are self-creating; they are, in Dworkin's view, a source of value in the way that God or nature might be for others. Dworkin, then, offers an interesting contribution about the possibilities of human creativity and his work is valuable to our discussion if only for that. More than that, though, the task that Perry assigns to nonreli- 
gious theorists (and that Dworkin sets for himself) - of providing a coherent secular understanding of a deeply religious concept - may very well be an impossible one and Dworkin's failure in this respect should not be emphasized excessively.

Although we have already looked, in detail, at these challenges to Dworkin's theory and at the problem of secularizing the concept of sacredness, we have not dealt with Perry's understanding of sacredness in its entirety. A crucial point left for us to consider is that Perry's conception of human sacredness can be said to encompass a number of the aforementioned "somethings" on which our rights rely. More specifically, Perry suggests that rights claims all rely on the notion that human beings are sacred, which is -in turn-based on the idea that we are the children of God. In addition, Perry contends that the sacredness of persons can be equated with the concept of inherent dignity that is highlighted in the Universal Declaration of Human Rights. His contention, however, is merely implied, for Perry (1998: 13) puts the two together only once-in a question - at the very beginning of his argument: "Or must we conclude that the idea of human rights is indeed ineliminably religious, that a fundamental constituent of the idea, namely, the conviction that every human being is sacred - that every human being is 'inviolable,' has 'inherent dignity,' is 'an end in himself,' or the like-is inescapably religious?" Perry seems to suggest that dignity and sacredness are, in fact, synonyms for one another. But this is too large an assumption, in my estimation, and too much hinges on it. Put succinctly, Perry wants to demonstrate that the sacredness of persons can only be understood religiously. Doing so, he claims, will mean that the idea of human rights is ineliminably religious. He fails to show, however, how it is that sacredness is necessarily connected to the idea of human rights; it is, instead, one of many possible foundations. Simply putting all these possibilities together and implying that they are derivative of human sacredness does not properly constitute an argument.

In a later chapter of his book, Perry is more forthcoming about his view of the connection between international law and the sacredness of persons. Indeed, he argues that the former is clearly derived from the latter: "Why is the good of every human being an end worth pursuing in its own right? ... One answer - the answer that informs the international law of human rights - is that the good of every human being is an end worth pursuing in its own right because every human being is sacred" (Perry 1998: 60). The problem, however, is that none of the international human rights documents actually uses this term. In fact, the language he examines from the International Bill of Human Rights does not contain the word "sacred" anywhere. As Perry (1998: 12) himself notes,

The ... Universal Declaration of Human Rights (1948), speaks, in the Preamble, of "the inherent dignity ... of all members of the human family" and of "the dignity and worth of the human person." In Article 1, the Declaration proclaims: "All human beings ... should act towards one another in a spirit of brotherhood." ... The preamble common to both [the International Covenant on Civil and Political Rights (1976) and the International Covenant on Economic, Social, and Cultural Rights (1976)] echoes the Universal Declaration in speaking of "the inherent dignity ... of all members of the human family." The preamble then states: "[T]hese rights derive from the inherent dignity of the human person ...." 
It is obvious that the idea of human rights, as understood in contemporary international documents, is based on the inherent dignity of persons. It is not immediately clear, however, where sacredness comes into the picture. Indeed, there is no mention of the sacredness of human beings in any international human rights document, and it is not necessarily the case that dignity and sacredness can be equated in the way that Perry assumes them to be.

In addition to suggesting that dignity and sacredness are intimately connected, Perry further implies that dignity is a religious concept. "What are we to make of such talk," he asks, "talk about 'the inherent dignity' of all human beings ... and about the importance, therefore, of all human beings acting toward one another 'in a spirit of brotherhood'? It is easy enough to understand such talk as religious talk" (Perry 1998: 13). And Perry is not alone in conflating these terms and assigning the same religious origin to both. Murphy (1988: 245) makes the same connection and, like Perry, does not offer an explanation for doing so: "The rich moral doctrine of the sacredness, the preciousness, the dignity of persons cannot in fact be utterly detached from the theological context in which it arose and of which it for so long formed an essential part." But should we assume that human dignity has the same theological foundation as human sacredness? In other words, are Perry and Murphy correct? Is the inherent dignity of persons just as religious (or religious in the same way) as the sacredness of persons? Perry goes to great lengths to suggest that sacredness is a fundamentally religious concept, but he has done nothing to conclusively show that dignity is similarly religious. If sacredness and dignity are not synonymous with one another, then Perry has not demonstrated that the idea of human rights is ineliminably religious. A brief glance at the language of the International Bill of Rights shows that dignity is clearly bound up with the concept of international human rights but not necessarily with sacredness; the latter, according to Perry, is an inextricably religious concept, but the former has not been similarly evaluated.

Indeed, Australian philosopher Raimond Gaita suggests that these concepts cannot be used interchangeably and do not carry the same weight. He does, however, agree with Perry that sacredness is a fundamentally religious concept and far more powerful than dignity. He notes (2002: 23),

\begin{abstract}
Only someone who is religious can speak seriously of the sacred, but such talk informs the thoughts of most of us whether or not we are religious ... . If we are not religious, we will often search for one of the inadequate expressions which are available to us to say what we hope will be a secular equivalent of it. We may say that all human beings are inestimably precious, that they are ends in themselves, that they are owed unconditional respect, that they possess inalienable rights, and, of course, that they possess inalienable dignity. In my judgment these are ways of trying to say what we feel a need to say when we are estranged from the conceptual resources we need to say it.
\end{abstract}

Although I am quite sympathetic to Gaita's position throughout A Common $\mathrm{Hu}$ manity, there is a problem that arises from the way in which he stakes out this particular argument, namely that the five examples of secular-and weak-versions 
of sacredness are not themselves synonyms. On my reading, Gaita seems to be lumping together actions and reasons for those actions. There is, for example, a clear discrepancy between the notion that "all human beings are inestimably precious" and the idea "that they are owed unconditional respect." Inestimable preciousness and inalienable dignity are similar, possibly secular, versions of the idea that people are sacred; the notion that people are owed unconditional respect and possess inalienable rights belong to an entirely different category. The difference is that the former concepts are the reasoning behind our believing the latter concepts. Indeed, the notions of sacredness and dignity are so vitally important precisely because of this difference; they provide the justification for our believing in the idea of human rights and the reason for our insistence that others act toward every human being as we do. Although this is problematic, however, a more pressing issue is whether Gaita or Perry is correct about the separation of dignity from sacredness. To untangle that question, it is necessary to gain a deeper understanding of both terms and it is to their etymological roots that we now turn.

\section{The Etymology of Rights}

The Oxford English Dictionary (Simpson and Weiner 1989: 338-339) lists seven definitions of "sacred," ranging from those that typically come to mind ("Secured by religious sentiment, reverence, sense of justice, or the like, against violation, infringement, or encroachment" and "Regarded with or entitled to respect or reverence similar to that which attaches to holy things") to those that are a bit more obscure ("Of the Eucharistic elements: Consecrated" and "Applied as a specific defining adj. to various animals and plants that are or have been considered sacred to certain deities"). Indeed, there are only two definitions that do not make reference to religion or a deity: first, "Accursed [After L. sacer; freq. translating or in allusion to Virgil's auri saca fames (Æn. III. 57)]," and second, "Dedicated, set apart, exclusively appropriated to some person or some special purpose" (Simpson and Weiner 1989: 338-339). The former provides us an opportunity to look into the Latin root, sacer, which-depending on context-could mean either "dedicated, consecrated, devoted, sacred," "accursed, execrable, detestable, horrible, infamous," or "regarded with reverence, holy, awful, venerable" (Lewis and Short 1969: 1610-1611). There is, to be sure, something strange about using the same word to mean both accursed and holy, but solving that mystery is not our present purpose. Instead, it is sufficient to note that the Latin root of a nonreligious definition returns us to religious language. Having done so, we can turn to the second of the two nonreligious definitions. Although it is not explicitly clear, with this definition, what might make "some person or some special purpose" sacred, a look at all of the other definitions of "sacred" seems to suggest that a relationship with a deity is most likely the source.

Having looked at the term "sacred" and noted the clear connection to "holy" and "religious" words in both English and Latin, it remains to us to consider "dignity" in the same manner. The Oxford English Dictionary (Simpson and 
Weiner 1989: 656-657) contains eight possible definitions, ranging once again from the very obvious ("The quality of being worthy or honourable; worthiness, worth, nobleness, excellence" and "Nobility or befitting elevation of aspect, manner, or style; becoming or fit stateliness, gravity") to the very obscure ("A situation of a planet in which its influence is heightened, either by its position in the zodiac, or by its aspects with other planets" and "The term for a 'company' of canons"). None of the definitions makes reference to the concepts of sacredness, holiness, or religion. Similarly, exploring the Latin root, dignus, does not help to connect sacredness and dignity; it is defined as "worthy, deserving (in a good or ill sense), of things, suitable, fitting, becoming, proper" (Lewis and Short 1969: 578). The Latin, in turn, can be traced back to the Greek $\delta \dot{\xi} \xi a$, which is defined as "expectation, notion, judgement, whether well grounded or not" or "the opinion which others have of one, estimation, repute" (Liddell and Scott 1959: 444). The only connection between "dignity" and "sacred" can be found in an obscure definition of "dignified," which usually is defined as "Invested with dignity; exalted" or "Marked by dignity of manner, style, or appearance; characterized by lofty self-respect without haughtiness; stately, noble, majestic" (Simpson and Weiner 1989: 656). The obscure definition, "Holding a position of dignity; ranking as a dignitary (esp. ecclesiastical)" (Simpson and Weiner 1989: 656), does provide a connection, albeit a very tenuous one, to a religious understanding of dignity.

Despite the fact that "dignified" once suggested that the clergy were highly ranked in society, the concept of dignity seems, on the whole, not to be related to the idea of human sacredness. Something is held sacred in virtue of a clear connection to some other holy thing. Sacredness can apply to objects and to people, and it provides the foundation for inviolability. In other words, human beings ought not to be violated because of their connection to the divine; likewise, human beings ought to be respected in much the same way that God is respected. The value of the object - in this case, a person - is fixed because of its unchanging relationship to the source of all value, God. The concept of dignity, conversely, applies only to people and traditionally only to a certain sort of person. It is, traditionally understood, an aristocratic concept. Unlike sacredness, which applies to all of the objects that are related to God, one must be worthy, noble, or honorable to be considered a bearer of dignity. One's dignity is, it seems, based on what others believe; in that sense, it is very much a subjective concept, as it is open to interpretation by definition. That said, it is important to note that our understanding of dignity has changed considerably in the last two hundred years. Before the revolutions in America and France in the eighteenth century, dignity and its attending esteem were strictly reserved for members of the nobility. With the collapse of the belief that a fraction of the populace was born into a position of greater worth, the concept of dignity underwent a considerable expansion. The Glorious Revolution of 1688-1689 provided a great deal of support to the idea that people might rightfully oppose a tyrannical government, but the American and French revolutionaries were the first to draw up a list of specific rights that applied, they said, to all men. ${ }^{10}$ 
Although the U.S. Declaration of Independence states that "all men are created equal" (Ishay 1997: 127) and the French Declaration of the Rights of Man and Citizen declares that "Men are born and remain free and equal in rights" (Ishay 1997: 138), neither makes mention of human dignity as the basis for this belief. And, perhaps not surprisingly, neither Declaration went to great lengths to ensure that the equality of rights applied equally to everyone. Clearly, the problem of slavery was not dealt with at the time of the signing of the U.S. Declaration, nor would it be dealt with in the lifetimes of the men who signed it. And, of course, the promulgation of the French Declaration was followed almost immediately by Robespierre's Terror and the execution of thousands by guillotine (including, eventually, Robespierre himself). Only ten years after proclaiming the Rights of Man and Citizen, political control over France was seized by Napoleon Bonaparte.

Despite what can graciously be termed serious problems of implementation, both the American and French Declarations are unequivocal in the principles that serve as their guide. In addition, the French revolutionaries provide support for the connection between human rights and sacredness, stating that they "have resolved to set forth in a solemn declaration the natural, inalienable, and sacred rights of man" (Ishay 1997: 138). And yet, despite the use of Perry's terminology, it is important to note that it is the rights that are sacred and not the people. Indeed, it is a bit of a mystery as to the reason behind the sacredness of the rights, which seems not to reside in the inherent equality of the people; this second concept, after all, requires a foundation of its own. It makes the most sense to assume that all men possess equally the sacred rights of "liberty, property, security, and resistance to oppression" because of their (unstated) connection to "the Supreme Being in the presence and under the auspices of [whom]" the rights were affirmed by the French National Assembly (Ishay 1997: 138). A similarly nondescript "Creator" appears in the American Declaration as well and is very clearly the source of man's "certain unalienable rights" (Ishay 1997: 127). Of primary importance to both the American and French Declarations, though, are the rights themselves, not their ultimate guarantor, because their infringement provided a rallying cry for the revolutions and their protection was at the heart of the radical democratic experiment that the revolutionaries proposed. And in fact, both revolutions promised to usher in an era of hitherto unimagined civil peace and religious tolerance, based on the complete absence of a state-sanctioned religion. ${ }^{11}$

Still the questions remain how and why the change from "natural, inalienable, and sacred rights" protected by a Supreme Being to the contemporary notion of the inviolability of persons based on their inherent dignity? I submit that a primary reason for the change is that, historically, the rights have not been held in practice to be particularly sacred. The UN Charter seems to bear this idea out:

We the peoples of the United Nations determined

to save succeeding generations from the scourge of war, which twice in our lifetime has brought untold sorrow to mankind, and to reaffirm faith in fundamental human rights, in the dignity and worth of the human person ... 
Have resolved to combine our efforts to accomplish these aims (Ishay 1997: 406).

Likewise, the Universal Declaration of Human Rights begins by noting that "disregard and contempt for human rights have resulted in barbarous acts which have outraged the conscience of mankind" (Ishay 1997: 407). Given the propensity that human beings have had, especially in the last century, for violating the rights enshrined in the American and French Declarations, the United Nations proposed a new way of understanding the duties that governments had to their citizens and, conversely, the rights those citizens could claim. ${ }^{12}$ According to Schulz (2002: 26), "What the Universal Declaration supplies all of us are rights in the form of norms to which every person can appeal, rights that ... are designed to depict the best way we know of at the moment to counter cruelty and build a decent society." Indeed, a statement by Eleanor Roosevelt, who chaired the Human Rights Commission that drafted the Universal Declaration, does much to confirm that its drafters appreciated the Declaration's revolutionary character:

We stand today at the threshold of a great event both in the life of the United Nations and in the life of mankind .... This Declaration may well become the international Magna Carta of all men everywhere. We hope its proclamation by the General Assembly will be an event comparable to the proclamation of the Declaration of the Rights of Man by the French people in 1789, the adoption of the Bill of Rights by the people of the United States, and adoption of comparable declarations at different times in other countries (Glendon 2001: 166).

In addition to this statement by Roosevelt, Charles Malik - the Lebanese philosopher and politician who ultimately shepherded the Declaration through the General Assembly-lends support to the idea that the community of nations stood on entirely new ground as it considered a rights instrument with the support of the entire world behind it. According to Malik,

Thousands of minds and hands have helped in its formation. Every member of the United Nations has solemnly pledged itself to achieve respect for and observance of human rights. But, precisely what these rights are we were never told before, either in the Charter or in any other international instrument. This is the first time the principles of human rights and fundamental freedoms are spelled out authoritatively and in precise detail. I now know what my government pledged itself to promote, achieve and observe when I had the honor to sign the [UN Charter]. I can agitate against my government, and if she does not fulfil her pledge, I shall have and feel the moral support of the entire world (Glendon 2001: 164).

Proposing such a list, however, is not the same as suggesting that the enumerated rights and the human dignity underlying them are objectively true. As Schulz (2002: 27) argues, "The question to ask about rights is not, Are they true? The question is, Do they work? Do they work to spread empathy, combat cruelty, and protect the weak from their oppressors? The experience of the international human rights community is that these do." Such an argument, though, seems to 
leave the idea of human rights on shaky ground; it is akin to admitting that, in fact, human rights might be a fad that could just as well not be in fashion tomorrow. Indeed, Schulz (2002: 26) recognizes this problem:

Such a concept of rights does not lend them the kind of irrefragable authority that God's will or Nature's command might. Theoretically, the Universal Declaration could be rescinded or amended. Human concepts of rights do change and there is no reason to believe that today's notions and norms will be identical to those of the twenty-second century any more than our norms are identical to those of the nineteenth.

This argument-that the idea of human rights and the human dignity that grounds it is constructed and therefore changeable-is one that is anathema to both Michael Perry and Ronald Dworkin, as both argue for the importance of a transcendent foundation for rights, one that is ultimately grounded in some feature or quality of humanity. The secular foundation that Dworkin proposes, however, is flawed for a variety of reasons, not the least of which is that it misunderstands the concept of sacredness on which it is based. But the task that he sets for himself and that Perry argues he fails to complete seems to me to be one that is both impossible and unnecessary. It is impossible, I argue, because the idea of secular sacredness is one that cannot be made sense of; it is unnecessary, I believe, because the concept of sacredness is not required to ground the idea of human rights in the way that Perry suggests. It is, instead, human dignity upon which the International Bill of Rights stands and it is possible that the concept of dignity for all humanity is a very recent development. Schulz, who is both a theorist and a practitioner of human rights, embraces the idea that we have recently established the ground upon which our rights stand and contends that this seemingly tenuous position need not dull the luster of human rights. Although this theory might not provide the sort of objectively strong defense that Perry requires, it is clear that no truly secular theory will be able to do so.

\section{Acknowledgments}

For ongoing extremely helpful discussions and comments, I am indebted to Bill Curtis, Peter Euben, Elizabeth Kiss, Michael Perry, and Dennis Rasmussen. I am also grateful for comments I received on earlier drafts of this article from Joel Kassiola and Ann Davies, as well as members of the Duke University Undergraduate Political Theory Colloquium. Thanks also to Chris Eberle and Michael Perry for allowing me to read and quote from unpublished manuscripts.

\section{Notes}

1. According to Weston (2002: 656), "Most students of human rights trace the historical origins of the concept back to ancient Greece and Rome, where it was closely tied to the pre-modern natural law doctrines of Greek Stoicism (the school of philosophy founded by Zeno of Citium, which held that a universal working force pervades all creation and that human conduct therefore should be judged according to, and brought into harmony with, the law of nature)." 
2. There are a wide variety of quotations from Eastern thinkers to support this point. Among my favorites are those pointed out by Schulz (2002: 183), that "Confucius himself asserted that 'an oppressive government is worse than a tiger,' " and Glendon (2001: 74), that "The Bengali Muslim poet and philosopher Humayin Kabir sounded a universalist note in writing about human rights and the Islamic tradition. Kabir proudly recalled that early Islam had 'succeeded in overcoming distinction of race and colour to an extent experienced neither before nor since.' " Of course, Schulz (2002: 183) goes on to point out the so-called Asian values critique of human rights, namely that "to advance human rights around the globe is to try to impose American values on other people and hence should be avoided has a certain logical ring to it. Mao was raised in the Chinese tradition. The Chinese tradition has no concept of human rights. To expect Mao to abide by them, therefore, is not only unfair but reflects an attempt to foist Western values on a different culture. The Chinese Communist Party may decree, as indeed it has, that Mao's merits outweigh his mistakes by a proportion of 7 to 3, but making judgments like that is not up to outsiders." Although Schulz clearly disagrees with this sort of logic, Glendon (2001: 73-74) offers a more powerful disagreement with those, like Singapore's Lee Kuan Yew, who argue that the idea of human rights is a Western construct that does not apply to Asian cultures: "The absence of formal declarations of rights in China, said Confucian philosopher Chung-Shu Lo, did not signify 'that the Chinese never claimed human rights or enjoyed the basic rights of man.' He explained: '[T]he problem of human rights was seldom discussed by Chinese thinkers of the past, at least in the same way as it was in the West. There was no open declaration of human rights in China, either by individual thinkers or by political constitutions, until this conception was introduced from the West. ... [However], the idea of human rights developed very early in China, and the right of the people to revolt against oppressive rulers was very early established. ... A great Confucianist, Mencius (372-289 B.C.), strongly maintained that a government should work for the will of the people. He said: 'People are of primary importance. The State is of less importance. The sovereign is of least importance.' " In addition, and perhaps even more pragmatic, are the words of Xiao Quiang, a Chinese dissident, at a 1998 Harvard symposium on the fiftieth anniversary of the Universal Declaration of Human Rights: "If you were to voice dissent from the prevailing view in China, you would end up in jail, and there you would soon be asking for your rights, without worrying about whether they were 'American' or 'Chinese' " (Glendon 2001: 232).

3. In the Confucian Analects, "Tse-kung asked, 'Is there one word that can serve as a principle of conduct for life?' Confucius replied, 'It is the word 'shu' - reciprocity. Do not impose on others what you yourself do not desire'" (15:23). The Islamic Forty Hadiths of an-Nawawi contends that "Not one of you is a believer until he desires for his brother what he desires for himself" (No. 13). In the Mahabharata of Hinduism, it is said, "Do naught to others which, if done to thee, would cause thee pain: this is the sum of duty" (5.1517). The Buddhist Majjhima Nikaya declares: "Is there a deed, Rahula, thou dost wish to do? Then bethink thee thus: Is this deed conducive to my own harm, or to others harm, or to that of both? Then is this a bad deed entailing suffering. Such a deed must thou surely not do" (1.415). This is by no means an exhaustive list, as it leaves out similar statements from Taoism, Sikhism, Shintoism, Zoroastrianism, and many others. These quotations and many others can found at the Ontario Consultants on Religious Tolerance website: http://www.religioustolerance.org/reciproc.htm

4. By way of an example, consider this passage about the freeing of slaves from Deuteronomy 15:1215: "If a fellow Hebrew, a man or a woman, sells himself to you and serves you six years, in the seventh year you must let him go free. And when you release him, do not send him away emptyhanded. Supply him liberally from your flock, your threshing floor and your winepress. Give to him as the Lord your God has blessed you. Remember that you were slaves in Egypt and the Lord your God redeemed you. That is why I give you this command today." It is interesting to note, of course, that this commandment applies to Jewish slaves only, but more important for our present purpose is that there is no manner by which the slave can protest if his owner chooses to disobey God's commandment and keep him in bondage for more than seven years. Any violation of the commandment is between God and the slave-owner; the owner clearly has a duty (to God) to release the slave, but the slave seems not to have an explicit right to his freedom.

5. I alternate between "human being" and "human life" throughout this article, as Perry writes of the former and Dworkin the latter. Although I recognize that these terms are charged, particularly within the literature on reproductive rights, I do not take a position on whether the concept of sa- 
credness best applies to one or the other. It seems sufficient to note, for the purposes of this article, that it does not seem odd to refer to either the sacredness of all human life or every human being. It might, however, be a bit of a stretch to refer to the inherent dignity of all human life, as opposed to every human being, for reasons discussed in greater length later in this article. My thanks to Allison Daniel Anders for a series of discussions that brought this important point to my attention.

6. There are, however, some things that tend to blur the distinction for Dworkin. Whereas art is intrinsically valuable, great art is sacred and might also-on occasion-be incrementally valuable. The same, he suggests, might be true of great lives: "even those who are most in favor of controlling population growth would not want fewer Leonardo da Vincis or Martin Luther Kings" (Dworkin 1994: 74). It seems, though, that the question of incremental value is ultimately a personal one; as Dworkin (1994: 74) tells us, "I do not myself wish that there were more paintings by Tintoretto than there are. But I would nevertheless be appalled by the deliberate destruction of even one of those he did paint." It is not terribly difficult to imagine someone who yearned for more Tintorettos and fewer da Vincis, and it is not immediately obvious from Dworkin's argument how this dispute might be adjudicated.

7. As Tomasi (1997: 493) correctly notes, "The crucial move, according to Dworkin, is to think of the creative inputs in people's lives, whether from nature (natural selection or, on some views, God's work) or from humans (culture and training), not simply as contributions but as investments." We can clearly understand what the investment is toward when considering a purely human investment, but it is considerably murkier with natural investments. The puzzle is that despite this difficulty, most people seem quite confident about whether or not their actions are respectful of natural investment: "When human projects, directly or indirectly, threaten an entire species of animal (consider the ivory hunting of the African elephant or the eradication of the snail darter by the Tellico Dam) most people are quite sure that this is a terrible thing, an act of desecration" (Tomasi 1997: 495). The puzzle is solved by what Tomasi terms the investment connection (IC) and, specifically, by the notion that IC is severed by what he calls a cross-basal violation when one closes an investment account opened by someone else. To flesh this idea out somewhat, consider the following example: "When a species of tree or animal naturally goes extinct, there seems to be a great subtraction of nature's creative investment. Yet people do not feel here ... that such an event is a violation of the sacred ... Since nature (theistic/secular) opened the account embodied in the tree species, when nature closes the account, IC has been preserved ... Imagine a different case whereby a community of young lumberjacks had developed a (to them) richly rewarding and meaningful life project centrally committed to the project of efficiently cutting down trees. Unfortunately, the remaining stand of some ... tree species gets in their way and is destroyed ... In both cases, the eradication of an entire tree species involves a great subtraction from what is wonderful in the world ... But, faced with uncertainty about what nature intends ... people feel the loss in the lumberjack case is worse because of the way the loss comes about: that loss involves what we might call a $s a-$ cred violation" (Tomasi 1997: 497-498). Despite all this talk about avoiding sacred violations, Tomasi might not be entirely correct, as two important examples help to highlight. Although it is true that most people worry about the extinction of beautiful, exotic, or helpful animals, the same cannot be said about the possibility of killing off nature's peskier creations. For example, mosquitoes are deliberately destroyed every minute of every day, and people do not so much as pause to consider that these creatures are a product of a great deal of natural investment. Mosquitoes are not on the verge of extinction, of course, but I am not confident that our decision to slap at them would change a great deal if they were. Similarly, few homeowners would be terribly upset if humankind found a way to exterminate crabgrass from the face of the planet. The distinctly human project of cultivating attractive lawns, especially when it involves strong chemicals to destroy weeds, is clearly disrespectful of nature's creative investment in crabgrass. These two examples call attention to the fact that not all of Tomasi's sacred violations are extremely troubling to most people; in fact, most people seem not to be concerned in the least about these sorts of cross-basal violations. Few people, if any, would suggest that human beings and mosquitoes represent equivalent creative investments, of course, which might account for the confidence that Dworkin has in our ability to figure out how much respect we owe to each.

8. There are, of course, other ways of in which people are awestruck that have no connection at all to sacredness. It is entirely possible for one to be filled with awe and find no value at all in the awesome object or event. Consider this famous description from Machiavelli (1985: 29-30): “And be- 
cause this point is deserving of notice and of being imitated by others, I do not want to leave it out. Once the duke had taken over Romagna, he found it had been commanded by impotent lords who had been readier to despoil their subjects than to correct them. ... So he put there Messer Remirro de Orco, a cruel and ready man, to whom he gave the fullest power. In a short time Remirro reduced it to peace and unity, with the very greatest reputation for himself. Then the duke judged that such excessive authority was not necessary.... And because he knew that past rigors had generated some hatred for Remirro, to purge the spirits of that people and to gain them entirely to himself, he wished to show that if any cruelty had been committed, this had not come from him but from the harsh nature of his minister. And having seized this opportunity, he had him placed one morning in the piazza at Cesena in two pieces, with a piece of wood and a bloody knife beside him. The ferocity of this spectacle left the people at once satisfied and stupefied."

9. At times, Dworkin (1994: 248) seems uncertain as to his own position on whether something can possess value independently of anyone valuing it: "I do not mean to take any position on a further, very abstract philosophical issue not pertinent to this discussion: whether great paintings would still be valuable if intelligent life were altogether destroyed forever so that no one could ever have the experience of regarding paintings again. There is no inconsistency in denying that they would have value then, because the value of a painting lies in the kind of experience it makes available, while still insisting that this value is intrinsic because it does not depend on any creatures' actually wanting that kind of experience."

10. In 1689, the English Bill of Rights recognized that "the late King James the Second, by the assistance of divers evil counselors, judges, and ministers employed by him, did endeavour to subvert and extirpate the protestant religion, and the laws and liberties of this kingdom" (Ishay 1997: 91). Although the Bill recognized that considerable violations of the citizens' rights had occurred under James, it concluded "that his said highness the prince of Orange will ... still preserve them from the violation of their rights, which they have here asserted, and from all other attempts upon their religion, rights, and liberties" (Ishay 1997: 93). Although the English had successfully challenged the notion that kings ruled by divine right, the Bill perpetuates the idea that a small subset of the population ought to rule over the commoners, provided they do so benevolently.

11. Whereas the English Bill of Rights recognized the necessity for Protestants to "have arms for their defense suitable to their conditions" (Ishay 1997: 92), the first two amendments to the Constitution of the United States of America hoped that weapons would only be "necessary to the security of a free state," since Congress could "make no law respecting an establishment of religion, or prohibiting the free exercise thereof" (Hamilton, et al. 1961: 542).

12. As Glover (2001: 3) points out, "To talk of the twentieth-century atrocities is in one way misleading. It is a myth that barbarism is unique to the twentieth century: the whole of human history includes wars, massacres, and every kind of torture and cruelty: there are grounds for thinking that over much of the world the changes of the last hundred years or so have been towards a psychological climate more humane than at any previous time. But it is still right that much of twentieth-century history has been a very unpleasant surprise. Technology has made a difference. The decisions of a few people can mean horror and death for hundreds of thousands, even millions, of other people. These events shock us not only by their scale. They also contrast with the expectations, at least in Europe, with which the twentieth century began."

\section{References}

Deuteronomy, Book of. (1986) The Holy Bible: New International Version (Grand Rapids: Zondervan Publishing House).

Dworkin, R. (1993) Life is sacred. That's the easy part. The New York Times Magazine, May 16.

Dworkin, R. (1994) Life's Dominion: An Argument about Abortion, Euthanasia, and Individual Freedom (New York: Vintage Books).

Eberle, C. (2003) Unnatural sacrifice (unpublished manuscript). 
Gaita, R. (2002) A Common Humanity: Thinking About Love and Truth and Justice (New York: Routledge).

Glendon, M. (2001) A World Made New: Eleanor Roosevelt and the Universal Declaration of Human Rights (New York: Random House).

Glover, J. (2001) Humanity: A Moral History of the Twentieth Century (New Haven: Yale University Press).

Grant, R. (1993) Abortion and the idea of the sacred. Times Literary Supplement, June 18.

Hamilton, A., Madison, J., and Jay, J. (1961) The Federalist Papers (New York: Penguin Books).

Ishay, M. (ed.). (1997) The Human Rights Reader: Major Political Writings, Essays, Speeches, and Documents from the Bible to the Present (New York: Routledge).

Kant, I. (1993) Grounding for the Metaphysics of Morals, trans. James W. Ellington (Indianapolis: Hackett Publishing Company).

Lewis, C. and Short, C. (1969) A Latin Dictionary (Oxford: Oxford University Press).

Liddell, H. and Scott, R. (1959) A Greek-English Lexicon, revised and augmented by Sir Henry Stuart Jones with the assistance of Roderick McKenzie (Oxford: Oxford University Press).

Machiavelli, N. (1985) The Prince. trans. Harvey C. Mansfield, Jr. (Chicago: University of Chicago Press).

Murphy, J. (1988) Afterword: constitutionalism, moral skepticism, and religious belief. In A. Rosenbaum (ed.). Constitutionalism: The Philosophical Dimension (New York: Greenwood Press).

Perry, M. (1994) The Gospel According to Dworkin. Constitutional Commentary, 11 (Winter).

Perry, M. (1998) The Idea of Human Rights: Four Inquiries (Oxford: Oxford University Press).

Perry, M. (May 12, 2003) Personal communication, email message to A. Kohen.

Perry, M. (2005) The morality of human rights: A nonreligious ground? Emory Law Journal, $54,97-150$.

Schulz, W. (2002) In Our Own Best Interest: How Defending Human Rights Benefits Us All (Boston: Beacon Press).

Simpson, J. and Weiner, E. (eds.). (1989) The Oxford English Dictionary (Oxford: Oxford University Press).

Tomasi, J. (1997) Liberalism, sanctity, and the prohibition of abortion. Journal of Philosophy, $94(10)$.

Weston, B. (2002) Human rights. The New Encyclopædia Britannica (Chicago: Encyclopædia Britannica).

Wittgenstein, L. (1968) Philosophical Investigations. trans. G. E. M. Anscombe (Oxford: Basil Blackwell). 